\title{
Phytochemical Screening, Nutritional and Toxicological Analyses of Leaves and Fruits of Solanum macrocarpon Linn (Solanaceae) in Cotonou (Benin)
}

\author{
Tamègnon Victorien Dougnon ${ }^{1,2 *}$, Honoré Sourou Bankolé2 ${ }^{2}$ Roch Christian Johnson ${ }^{1}$, \\ Jean Robert Klotoé ${ }^{2}$, Godfried Dougnon ${ }^{3}$, Fernand Gbaguidi ${ }^{4}$, Fidèle Assogba ${ }^{5}$, Joachim Gbénou ${ }^{5}$, \\ Salifou Sahidou ${ }^{2}$, Jean-Marc Atègbo ${ }^{6}$, Bertrand Henri Rihn ${ }^{7}$, Frédéric Loko ${ }^{2}$, Michel Boko ${ }^{1}$, \\ Aléodjrodo Patrick Edorh ${ }^{1,8}$
}

\begin{abstract}
${ }^{1}$ Laboratory of Toxicology and Environmental Health, Interfaculty Center of Formation and Research in Environment for the Sustainable Development, University of Abomey-Calavi (UAC), Cotonou, Benin; ${ }^{2}$ Research Laboratory in Applied Biology, Polytechnic School of Abomey-Calavi, University of Abomey-Calavi, Cotonou, Benin; ${ }^{3}$ Unit of Training and Research in Pharmacy, Faculty of Health Sciences, Champ de Foire, Cotonou, Benin; ${ }^{4}$ National Laboratory of Pharmacognosy, Benin Center of Scientific and Technical Research, and Essential Oils, Porto-Novo, Benin; ${ }^{5}$ Laboratory of Pharmacognosy and Essentials Oils, Institute of Applied Biomedical Sciences, Champ de Foire, Cotonou, Benin; ${ }^{6}$ Department of Animal Physiology, Faculty of Science and Technology, University of Abomey-Calavi (UAC), Cotonou, Benin; ${ }^{7}$ CITHéFOR, Université de Lorraine, Nancy, France; ${ }^{8}$ Department of Biochemistry and Cellular Biology, Faculty of Science and Technology, University of Abomey-Calavi (UAC), Cotonou, Benin. Email: *victorien88@hotmail.com
\end{abstract}

Received September $15^{\text {th }}$, 2012; revised October $15^{\text {th }}, 2012$; accepted October $22^{\text {nd }}, 2012$

\begin{abstract}
Vegetables are very important sources of protein and minerals. Some of them even have medicinal properties recognized traditionally. Despite the large number of studies carried out on various vegetables and vegetable crops, very few have scientifically explored the usefulness of $S$. macrocarpon. This study identified the main groups of chemicals and mineral elements to explain any medicinal or nutritional value. It has also identified some toxic elements contained in this vegetable. Phytochemical screening was carried out on the leaves and fruits of $S$. macrocarpon. Some mineral elements were determined by Atomic Absorption Spectrophotometry (sodium, potassium, calcium, magnesium) while protein, phosphorous, iron, copper, zinc and toxic metals (lead, cadmium) were determined by Molecular Absorption Spectrophotometry. Fat, ash, moisture and vitamins were sought. The study showed that the leaves of $S$. macrocarpon were more nutritious than fruits $(\mathrm{P}<0.05)$. The high protein content of the leaves and fruit suggests an interesting nutritive property. The presence of chemical groups and toxic elements (lead, cadmium) in $S$. macrocarpon require that the consumption of vegetables should be as varied as possible and that the fruit may be consumed with caution. In addition, constraints about vegetable cultivation in Cotonou could lead to research findings that could help provide techniques for producing healthy vegetables.Vitamins A and K1 were found in both parts of this vegetable very rich in water while vitamin E has not been detected. S. macrocarpon also contains lipids at various levels.
\end{abstract}

Keywords: S. macrocarpon; Nutrients; Minerals; Lead; Cadmium; Cotonou

\section{Introduction}

S. macrocarpon is a vegetable commonly called "Gboma" in the local language (Fon) in Benin. It is a plant of the family Solanaceae like tomato, pepper and eggplant [1]. The botanical genus includes herbaceous plants or shrubs; leaves are usually alternate, sometimes opposite. The inflorescence is a cyme, usually single seed. The flowers are hermaphrodite, with star-shaped corolla with five petals often returned back. The protruding stamens form a cone around the gynoecium. The ovary is superior.

${ }^{*}$ Corresponding author.
Worldwide, there are about 1500 species of the genus Solanum [2]. The choice of $S$. macrocarpon by this study is justified by the fact that whereas its nutritional properties as a vegetable are appreciated by consumers [3], this plant seems to be of interest in traditional medicine [4]. Indeed, in Sierra Leone, heated leaves are chewed to treat throat problems [2]. In Nigeria, the fruits are eaten as laxatives and are used in the treatment of heart disease while the flowers and fruits are chewed for cleaning the teeth [2]. The leaves and young fruits are prepared and eaten as a vegetable [4]. In Kenya, the juice of boiled roots is drunk to get rid of hookworms while the crushed 
leaves are used to treat stomach disorders [2]. In addition, $S$. macrocarpon has laxative and hypotensive properties [5]. The aqueous extract of fruits showed hypolipidemic activities and hepatoprotective effects [2]. Having noticed that all parts of this plant (fruits, leaves, etc.) are used either in the diet or in the treatment of several diseases, this study is proposed as a first step to make a comparative phytochemical screening between the leaves and fruits of $S$. macrocarpon. It then sought the nutriational value of these two parts of the plant. Despite these virtues ascribed to this vegetable, its conditions of production in Cotonou have several problems. Indeed, preliminary studies showed that the use of chicken manure for cultivation of vegetables, increasingly adopted by gardeners, infected the leaves by heavy toxic metals (lead, cadmium) and enterobacteria such as Escherichia coli [6]. This is why the study explored in a third time the toxicological properties of these two parts of this vegetable product by nearly $95 \%$ of market gardeners in Benin [7]. Despite the existence of recent studies on the fruits of $S$. macrocarpon [5,7], no study has really looked at the leaves of this vegetable. In addition, fruits studied by these authors were not necessarily the same variety as those of the present study. In Benin, no data of this kind about the leaves and fruits of $S$. macrocarpon existed.

\section{Materials and Methods}

\subsection{Materials}

The mature leaves and fruit of S. macrocarpon (Figure 1) were used in this study. They were purchased in July 2012 from the garden site of Houéyiho locatedat $6^{\circ} 21^{\prime} 20^{\prime \prime}$ North latitude and $2^{\circ} 21 ' 35 "$ East longitude in the Republic of Benin. The plant was identified and authenticated by the National Herbarium of Benin under No. 6423 AA/HNB of 31st July 2012.

\subsection{Methods}

\subsubsection{Preparation of the Plant for Testing}

The leaves were dried at $16^{\circ} \mathrm{C}$ in the Research Laboratory in Applied Biology, University of Abomey-Calavi for 17 days while the fruits were finely cut into small pieces and dried for 9 days. The leaves and dried fruits were ground for ten minutes using a SAYONA MOULINEX commercially purchased. The powders obtained were sieved using two sieves of $0.2 \mathrm{~mm}$ (mesh size) and stored in sterile containers until needed.

\subsubsection{Phytochemical Screening}

These tests were made on the basis of differential reactions (coloration and precipitation) of the major groups

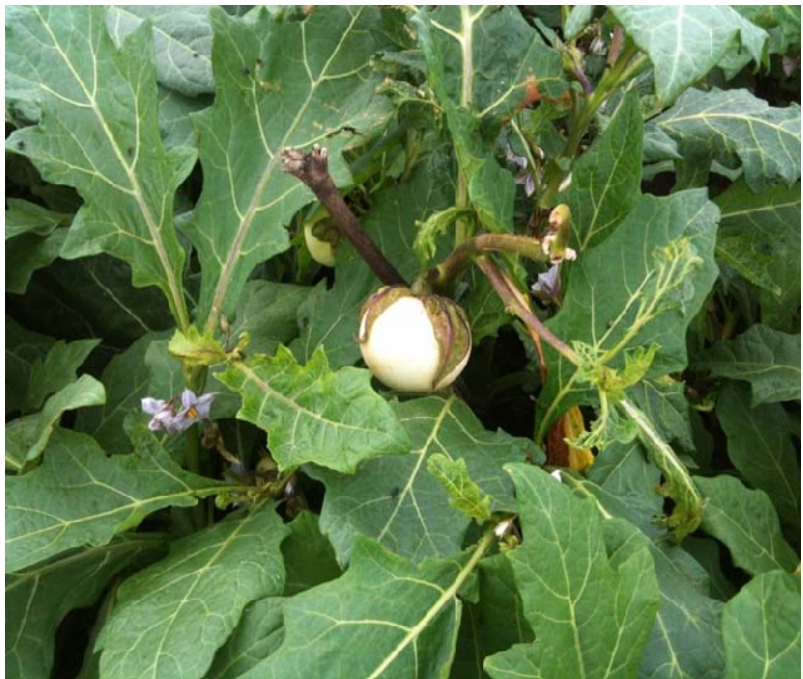

Figure 1. Mature leaves and fruits of $S$. macrocarpon grown in Cotonou.

of chemical compounds contained in the plant according to the method of Houghton et Rama [8] reviewed and adapted to the conditions of the Laboratory of Pharmacognosy and Essential Oils of Institute of Applied Biomedical Sciences (Benin). Powders of the leaves and fruits were used and various chemical compounds were investigated (Table 1).

\subsubsection{Determination of Nutrients}

The first step was to mineralize powders of the leaves and fruits by the procedure described by Hach [9]. Sodium, potassium, calcium and magnesium were assayed both in leaves and fruits by Atomic Absorption Spectrophotometry (Atomic Absorption Spectrophotometer VARIAN SPECTRA 110 with flame) in Laboratory of Soil Science, Water and Environment/Research Center of Agonkanmey/National Institute for Agricultural Research of Benin while phosphorus, protein, iron, copper and zinc were determined by Absorption Molecular Spectrophotometry (Spectrophotometer DR 2800) in Quality Control of Water and Food Laboratory (Ministry of Health, Benin).

\subsubsection{Determination of Sodium, Potassium, Calcium and Magnesium}

Powders of the leaves and fruits were incinerated in a muffle furnace at $550^{\circ} \mathrm{C}$ for 24 hours. The ash thus obtained was dissolved in $2 \mathrm{~mL}$ of hydrochloric acid $(\mathrm{HCl})$ $6 \mathrm{~N}$ which was evaporated on a hot plate at $125^{\circ} \mathrm{C}$. The more or less viscous remaining obtained was again dissolved and recovered using nitric acid $\left(\mathrm{HNO}_{3}\right) 0.1 \mathrm{M}$ in a $100 \mathrm{~mL}$ flask. The solution obtained was used, either diluted or not, to assay components in accordance with EN14082 reference standards. 

of Solanum macrocarpon Linn (Solanaceae) in Cotonou (Benin)

Table 1. Chemical groupspresent in theleaves and fruits of $S$. macrocarpon.

\begin{tabular}{|c|c|c|c|c|}
\hline Chemical groups & $\begin{array}{l}\text { Leaves of } \\
\text { S. } \text { macrocarpon }\end{array}$ & Observations on leaves & $\begin{array}{l}\text { Fruits of } \\
\text { S. macrocarpon }\end{array}$ & Observations on fruits \\
\hline Alkaloids (mayer’s test) & + & Fishyprecipitate & +++ & Fishyprecipitate \\
\hline Quinone derivatives (born-trager reaction) & - & $\begin{array}{l}\text { No pink or purplish red } \\
\text { coloration }\end{array}$ & - & $\begin{array}{l}\text { No pink or purplish red } \\
\text { coloration }\end{array}$ \\
\hline Tannins (ferric chloride test) & ++ & Black coloration & ++ & Black coloration \\
\hline Cathetic tannins (stiasny test) & - & No precipitate & ++ & No precipitate \\
\hline $\begin{array}{l}\text { Gallic tannins (ferric chloride test after } \\
\text { saturation with sodium acetate) }\end{array}$ & + & Slight blue tint & ++ & Blue tint \\
\hline $\begin{array}{l}\text { Flavonoids (shinoda test and magnesium } \\
\text { powder) }\end{array}$ & - & No coloration & - & No coloration \\
\hline Cyanogenic derivatives (picric acid test) & - & $\begin{array}{l}\text { No brown coloration on paper } \\
\text { soaked in picric acid }\end{array}$ & - & $\begin{array}{l}\text { No brown coloration on paper } \\
\text { soaked in picric acid }\end{array}$ \\
\hline $\begin{array}{l}\text { Triterpenoids (acetic acid test }+ \text { mixture of } \\
\text { acetic an hydride and sulfuric acid) }\end{array}$ & - & No blue color, green or purple & - & No blue color, green or purple \\
\hline Steroids (kedde reaction) & - & No red color purple & - & No red color purple \\
\hline Cardenolides (raymond reaction) & - & No blue coloration & - & No blue coloration \\
\hline Saponins (test index foam) & ++ & $\begin{array}{l}\text { Presence of foam greater than } 1 \\
\mathrm{~cm}\end{array}$ & - & Negligible presence of foam \\
\hline $\begin{array}{l}\text { Anthocyanins (test with hydrochloric acid } \\
\text { and ammonia diluted to half) }\end{array}$ & - & No coloration & - & No coloration \\
\hline Leucoanthocyanes (shinoda test) & - & No coloration & - & No coloration \\
\hline Mucilage (test of absolute alcohol) & +++ & Flocculent precipitate & +++ & Flocculent precipitate caked \\
\hline $\begin{array}{l}\text { Reducing compounds (test with fehling's } \\
\text { solution) }\end{array}$ & +++ & Red precipitate & +++ & Red precipitate \\
\hline $\begin{array}{l}\text { Free anthracene derivatives (test with } \\
\text { chloroform andammonia) }\end{array}$ & - & No red color & - & No red color \\
\hline $\begin{array}{l}\text { Combined anthracene derivatives (test with } \\
\text { chloro form andammonia) }\end{array}$ & - & No staining & - & No staining \\
\hline
\end{tabular}

+ = Weak presence; - = Absence; ++ = Moderate presence; $+++=$ High presence.

\subsubsection{Protein Assay}

This was determined according to Kjeldahl method, which consisted of sampling $10 \mathrm{~mL}$ of the mineralized solution to which $1 / 10$ of potassium hydroxide $(\mathrm{KOH}) 12$ $\mathrm{N}$ was added. Respectively 3 drops of mineral stabilizer and polyvinyl alcohol were made to blend. After up to 25 $\mathrm{ml}$ in reading tub with distilled water, $1 \mathrm{~mL}$ of NESSLER reagent was added before reading against distilled water treated in the same manner. This method yielded Kjeldahl nitrogen (TKN) by the following formula:

$$
\mathrm{TKN}(\mathrm{mg} / \mathrm{kg})=75 \times \mathrm{A} / \mathrm{B} \times \mathrm{C}
$$

with $\mathrm{A}=$ value read in $\mathrm{mg} / \mathrm{L}, \mathrm{B}=$ weight committed during mineralization and $\mathrm{C}=$ Volume collected for analysis The detection limit of the apparatus is $1 \mathrm{mg} / \mathrm{L}$ and the protein rate was obtained by multiplying the previous results by a factor of 6.25 [9].

\subsubsection{Determination of Iron, Copper, Zinc and Phosphorus}

A known volume was neutralized ( $\mathrm{pH}$ between 4 and 5) by addition of sodium hydroxide $(\mathrm{NaOH}) 5 \mathrm{~N}$. The final volume was adjusted with distilled water in a known proportion. The reagents used for the assay were those recommended by [9]. Methods to Ferrozine (Method 8147) for the iron, to Bicinchoninate (Method 8026) for copper, ZINCOVER (Method 8009) for zinc and ascorbic acid (Method 8048) for phosphorus were used in accordance with instructions of Hach [9].

The following formulae were used to obtain the various results:

$$
\begin{gathered}
\mathrm{mg} / \mathrm{kg}(\mathrm{Fe}, \mathrm{Cu}, \mathrm{P})=\mathrm{A} \times 2500 / \mathrm{B} \times \mathrm{C} \\
\mathrm{mg} / \mathrm{kg}(\mathrm{Zn})=\mathrm{A} \times 2500 / \mathrm{B} \times \mathrm{C}
\end{gathered}
$$

with $\mathrm{A}=$ value read on the apparatus in $\mathrm{mg} / \mathrm{L}$; $\mathrm{B}=$ 
weight committed during mineralization and $\mathrm{C}=$ Volume collected for analysis

\subsubsection{Determination of Fat, Ash, Moisture and Vitamins}

\section{Determination of fat, ash and water content}

Lipids were measured in both the leaves and fruits using the methodology described by Gbaguidi [10]. Ash and fiber have been investigated by the methods of the Association of Official Analytical Chemists namely section 923.03 for ash [11]. The water content of leaves and fruits of $S$. macrocarpon was assessed according to the methodology of Audigie et al. [12].

\section{Determination of fat-soluble vitamins}

Vitamins A, E and K1 were determined by HPLC using the method described below:

Preparation of stationary phase

It consists of a washing of the plate which is put vertically in a tank containing $50 \mathrm{~mL}$ of isopropanol for one hour. Then, the plate was removed and dried at $120^{\circ} \mathrm{C}$ in an oven for 30 minutes.

Preparation of standard solution of vitamin

This was a methanolic solution of $1 \mathrm{mg} / \mathrm{ml}$ prepared by dissolving retinol, $\alpha$-tocopherol and vitamins A, E, K1 standard in methanol.

Preparation of sample

After weighing $2 \mathrm{~g}$ of sample into a $50 \mathrm{~mL}$ flask, add $10 \mathrm{~mL}$ of $\mathrm{n}$-hexane on the test and leave for one hour with continuous stirring and then sonicate the whole for $30 \mathrm{~min}$ at ultrasound. Decant and collect $5 \mathrm{~mL}$ of filtrate into a $12 \mathrm{~mL}$ vial covered with aluminum foil and then evaporate together until dry. Take the dry residue in the flask with $5 \mathrm{~mL}$ of methanol and sonicate for $5 \mathrm{~min}$. Filter the resulting solution in a small vial of $3 \mathrm{~mL}$.

\section{Analysis by HPTLC-D}

$1 \mathrm{~mL}$ of each sample extract and the standard solution was introduced into vials of apparatus which deposits on a stationary phase consisting of HPTLC Silica gel 60 F254s $20 \times 10$ (Merck) plate. Deposed volumes were 2, 3 and $5 \mathrm{~L}$ of retinol for the standard and 1, 2, 3, $5 \mathrm{~L}$ for standard $\alpha$-tocopherol and vitamins and $10 \mu \mathrm{L}$ for samples. Deposits were bands of $6 \mathrm{~mm}$ long and spaced by $11.2 \mathrm{~mm}$. After deposition, the plate was removed, dried in air for 10 minutes and developed in a conventional tank of dimension $20 \times 20 \mathrm{~cm}$ with the mobile phase consisting of the mixture acetone-methanol in the proportions $8: 2 \mathrm{v} / \mathrm{v}$. The saturation time of the plate was 15 minutes. Migration distance was $80 \mathrm{~mm}$.

The plate was then removed from the tank, dried and observed at UV and placed in the Camag TLC Scanner III densitometer and read at $254 \mathrm{~nm}$. Then the data were acquired and processed by the software winCATS 1.2.4.

Based on the amount deposited on the plate and the extraction volume, we determined the expression of the vitamin content given by the relation:

$$
\mathrm{T}(\mu \mathrm{g} / 100 \mathrm{~g})=5.10^{4} \mathrm{q}
$$

with q the quantity $(\mu \mathrm{g})$ of vitamin in10 $\mu \mathrm{L}$ filed.

\subsubsection{Toxicological Tests}

Lead and cadmium were detected by Molecular Absorption Spectrophotometry (Spectrophotometer DR 2800) with dithizone [9]. After the mineralization phase, $20 \mathrm{~mL}$ of the mineral deposit were taken and made up to 250 $\mathrm{mL}$ with distilled water in a separating funnel fitted with taps, following the procedure for the extraction of cadmium and lead in pure chloroform recta [9]. A comparative reading with chloroform on the molecular absorption spectrophotometer DR 2800 was made.

The detection limits of the apparatus were $1 \mathrm{mg} / \mathrm{L}$ for lead and $0.2 \mathrm{mg} / \mathrm{L}$ for cadmium. The results were obtained by applying the following formula:

$$
\begin{aligned}
& \mathrm{Cd}(\mathrm{mg} / \mathrm{kg})=25 \times \mathrm{A} / \mathrm{B} \times \mathrm{C} \\
& \mathrm{Pb}(\mathrm{mg} / \mathrm{kg})=25 \times \mathrm{A} / \mathrm{B} \times \mathrm{C}
\end{aligned}
$$

with $\mathrm{A}=$ value read on the apparatus in $\mathrm{mg} / \mathrm{L} ; \mathrm{B}=$ weight committed during mineralization and $\mathrm{C}=$ Volume collected for analysis

\subsubsection{Statistical Tests}

Mann Whitney test which is a nonparametric test of comparing two by two averages was used. Assays for each parameter were repeated three times and the software Stat XL 2011 was used to compare the different values obtained for the leaves and fruit. A significance level of $\alpha=0.05$ was set. The results are presented as Mean \pm Standard Deviation (SD) for nutrients and toxic values.

\section{Results and Discussion}

\subsection{Results}

\subsubsection{Phytochemical Screening of the Leaves and Fruits of $S$. macrocarpon}

Chemical groups present in both the leaves and fruits of this plant are presented in Table 1. The leaves of $S$. macrocarpon contain alkaloids, gallic (hydrolysable) tannins, mucilages, saponins and reducing compounds while the fruits contain alkaloids, cathetic (non-hydrolysable) and gallic (hydrolysable) tannins, mucilages, reducing compounds and coumarins.

\subsubsection{Nutritional Analyses of the Leaves and Fruits of S. macrocarpon}

The leaves of $S$. macrocarpon contain amounts of so- 
dium, potassium, calcium, magnesium, iron, copper, zinc and protein greater than those contained in the fruit $(\mathrm{P}<$ 0.05) (Table 2). On the other side, fruits contain more phosphorus $(5100 \pm 1 \mathrm{mg} / \mathrm{kg})$ than leaves $(4300 \pm 2$ $\mathrm{mg} / \mathrm{kg})(\mathrm{P}<0.05)$. The leaves and fruit of this vegetable contain lipid at respectively levels of 21,670 $\pm 71 \mathrm{mg} / \mathrm{kg}$ and $16,470 \pm 19 \mathrm{mg} / \mathrm{kg}$. The leaves and fruits are rich in water (respectively $88.6 \%$ and $92.9 \%$ ). The total ash content ranged from $90.23 \%$ for fruits to $92.58 \%$ for the leaves. In addition, vitamin A was detected in both leaves (3530 mg/kg) and fruit (3680 mg/kg). It is the same for vitamins $\mathrm{K} 1$ found at varied levels in fruit $(1320 \mathrm{mg} / \mathrm{kg})$ and leaves $(55 \mathrm{mg} / \mathrm{kg}$ ). There was no presence of vitamin E in S. macrocarpon (Table 2).

\subsubsection{Toxicological Tests}

The leaves and fruits of $S$. macrocarpon were contaminated by lead and cadmium. The leaves $(1.2 \pm 0.1 \mathrm{mg} / \mathrm{kg})$ were less contaminated by lead than fruits $(1.6 \pm 0.1 \mathrm{mg} /$ $\mathrm{kg})(\mathrm{P}<0.05)$ while there was no significant difference between the leaves $(0.4 \pm 0.01 \mathrm{mg} / \mathrm{kg})$ and fruits $(0.4 \pm$ $0.03 \mathrm{mg} / \mathrm{kg}$ ) with respect to the level of contamination by cadmium (Figure 2).

\subsection{Discussion}

\subsubsection{Phytochemical Screening}

This study found that the leaves and fruits of $S$. macrocarpon have a different chemical composition. The
Table 2. Nutritional value of the leaves and fruits of $S$. macrocarpon.

\begin{tabular}{ccc}
\hline Parameters sought & $\begin{array}{c}\text { Quantity in leaves } \\
\text { (mg/kg) }\end{array}$ & $\begin{array}{c}\text { Quantity in fruits } \\
\text { (mg/kg) }\end{array}$ \\
\hline Sodium & $1760.33 \pm 1.52 \mathrm{a}$ & $1370.33 \pm 1.52 \mathrm{~b}$ \\
Potassium & $45,960 \pm 1.00 \mathrm{a}$ & $37,410 \pm 1.00 \mathrm{~b}$ \\
Calcium & $19,650 \pm 1.00 \mathrm{a}$ & $3770 \pm 1.00 \mathrm{~b}$ \\
Magnesium & $5960 \pm 1.00 \mathrm{a}$ & $2430 \pm 1.00 \mathrm{~b}$ \\
Iron & $251 \pm 1.00 \mathrm{a}$ & $203 \pm 1.00 \mathrm{~b}$ \\
Copper & $40 \pm 1.00 \mathrm{a}$ & $34 \pm 1.00 \mathrm{~b}$ \\
Zinc & $220 \pm 1.00 \mathrm{a}$ & $156 \pm 1.00 \mathrm{~b}$ \\
Protein & $271,600 \pm 1.00 \mathrm{a}$ & $147,000 \pm 1.00 \mathrm{~b}$ \\
Phosphorus & $4300 \pm 2.00 \mathrm{a}$ & $5100 \pm 1.00 \mathrm{~b}$ \\
Fat & $21,670 \pm 71 \mathrm{a}$ & $16,470 \pm 19 \mathrm{a}$ \\
Water content & $88.6 \%$ & $92.9 \%$ \\
Ash & $92.58 \%$ & $90.23 \%$ \\
Vitamin A & 3530 & 3680 \\
Vitamin K1 & 55 & 1320 \\
Vitamin E & - & - \\
\hline
\end{tabular}

Means with different letters in different columns are significantly different at significance level $\alpha=0.05$.

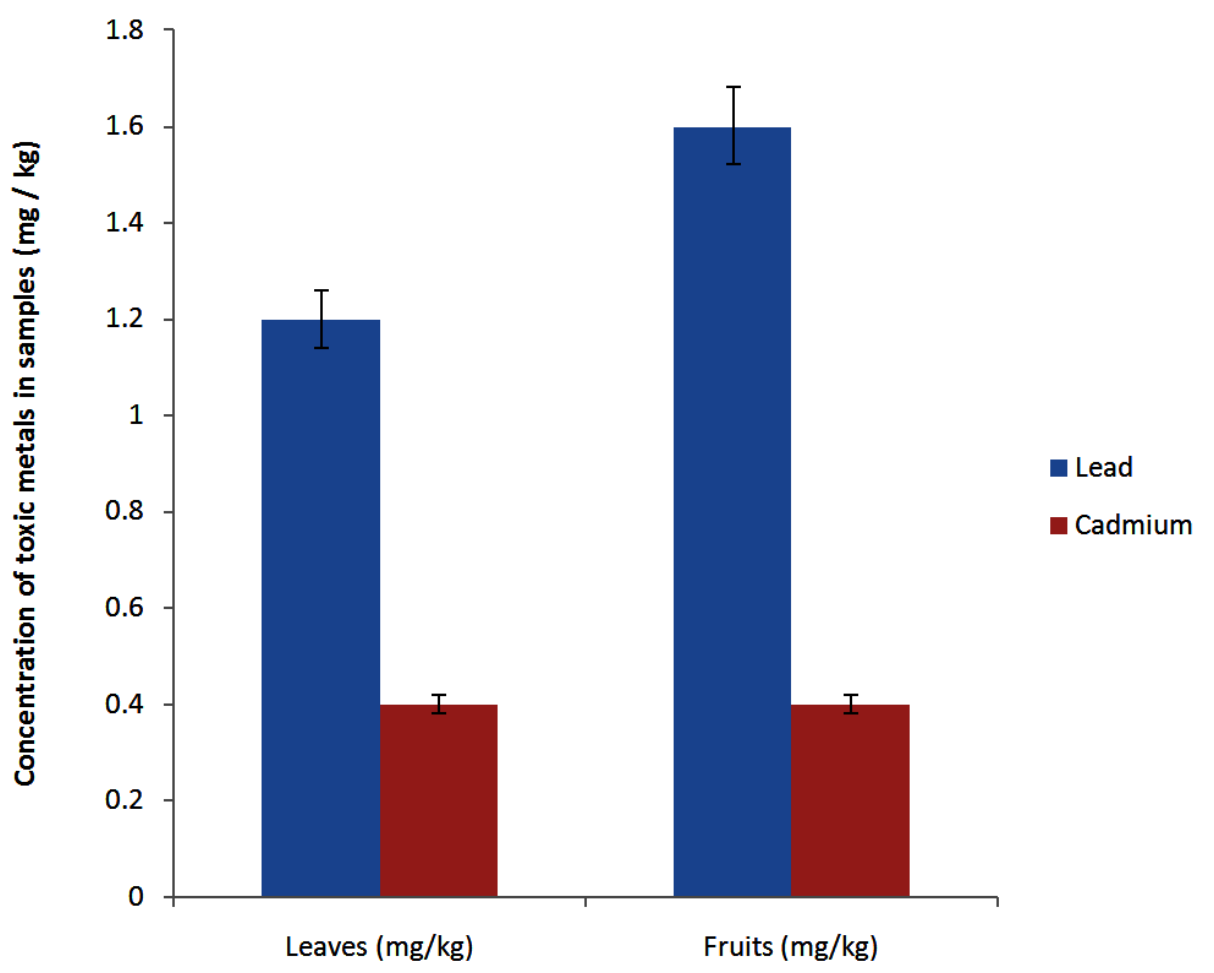

Figure 2. Contamination level of the leaves and fruits of $S$. macrocarpon by lead and cadmium. 
leaves contain alkaloids, gallic tannins (hydrolysable), mucilages, saponins and reducing compounds. The interest of this part of the study is that such investigation on leaves of this vegetable has never been made so far to determine whether the consumption of $S$. macrocarpon is actually free from hazard or not. Thus, according to the work of [13], tannins (especially hydrolysable) present in many plant foods have been identified as being responseble, in large doses, in decreasing in the rate of growth, protein digestibility in laboratory animals. The incidence of some cancers, such as esophageal cancer, has been linked to the consumption of foods rich in tannins, suggesting that tannins may be carcinogenic [13]. Nevertheless, the low presence of this antinutritional substance in the leaves of $S$. macrocarpon revealed by this study allows consumption. [14] for this purpose, revealed that the low concentration of tannins in vegetable is associated with positive effects on digestion. However, excessive daily consumption of this vegetable should be avoided as far as possible. The same suggestion was made by [15] who found traces of tannins in high consumption vegetable in Nigeria (Brassica oleracea). The fruits of $S$. macrocarpon contain hydrolysable tannins in a moderate proportion. These results are confirmed by the work of [5] in Nigeria who emphasized astringent properties of tannins and their physiological role in the treatment of injuries, which is not beneficial when compared to the harm that their strong presence in a vegetable can cause. Similarly, [16] have identified a moderate proportion of tannins in the fruits of S. macrocarpon in Nigeria. Unlike the leaves, these fruits contain a moderate amount of another type of non-hydrolysable tannins called cathetic tannins. The presence of total tannins (gallic + cathetic) in fruits suggests moderate consumption of this part of the vegetable. This situation explains why the leaves are widely consumed more than the fruits in Benin. The presence of alkaloids in the leaves (in small amount) and fruits (high proportion) suggests analgesic, anti-inflammatory properties and an increase in the potential for disease resistance and stress [17]. $S$. macrocarpon contains solanidine and solasodine which are toxic alkaloids [18]. The alkaloids found in this plant are responsible for its lipid-lowering activity. This explains why fruits are preferred to leaves in the treatment of cholesterol disorders in Nigeria $[5,18]$. However, because of the presence of toxic principles, the consumption of fruit must be strictly controlled. Until then, only the consumption of unripe fruit has been reported by a scientific study [18]. Mucilages are polysaccharides reported as antioxidants [19]. The strong presence of these compounds in the leaves as well as in the fruit probably implies that $S$. macrocarpon could present interesting antioxidant properties, which is important from a re- search perspective. The leaves and fruits of $S$. macrocarpon are rich in reducing compounds. The results of this study are confirmed by the work reported by [5] which revealed the presence of reducing sugars in the fruits of this vegetable. These reducing sugars are monosaccharides and disaccharides [20,21]. Vegetables mostly contain enough carbohydrates and reducing compounds. This is why it is advisable to have a varied diet rich in vegetables. The leaves of $S$. macrocarpon grown in Cotonou have a moderate amount of saponins. These chemicals are important dietary and nutritional reserves [16]. Saponins are glycolsidic in nature [5]. They have an expectorant action useful in the management of upper respiratory tract infections. According to [22], saponins are involved in the treatment of hypercholesterolemia. However, this study did not reveal their presence in the fruit. This result differs from those of [5] and [16] who have respectively found a moderate amount and a large quantity. These differences may be explained by the fact that our study was conducted in Cotonou (Benin), while others were carried out in two different regions of Nigeria. In addition, this study took into account the mature fruit, which is not necessarily the case in other studies. The fruits of $S$. macrocarpon contain a moderate amount of coumarins unlike leaves. This presence of coumarins in the fruit could make them exhibit anticoagulant, antimicrobial and spasmodic effects, a set of pharmacological properties recognized for coumarins [23]. Moreover, according to [24], testing for coumarins also highlights flavonoids and quinones. If this test is positive in the absence of flavonoids and quinones, as in the case in our study, the detection of coumarins is confirmed. The absence of steroids in fruits and leaves of $S$. macrocarpon was confirmed by the work of [16] on the fruits of $S$. macrocarpon grown in Nigeria. These authors also found flavonoids in the fruits, which is not the case in this study. The geographical origin of the samples could explain this difference, but the work done by [5] gave negative results consistent with those of the present study using the same method of Shinoda. The difference would then come from the method used by [16], which did not show, in addition, a strong presence of flavonoids in fruits of $S$. macrocarpon.

\subsubsection{Nutritional Value of the Leaves and Fruits of $S$. macrocarpon}

Several essential trace elements have some effects on various functions of people depending on their physiological or toxic concentrations [5]. The present study showed that the leaves of $S$. macrocarpon are richer in sodium, potassium, calcium, magnesium, iron, copper, zinc and protein when compared to the fruits that have a higher content of phosphorus ( $\mathrm{P}<0.05)$. However, the 
levels of these elements are quite high in these two parts of the plant. Calcium regulates a great number of physiological and biochemical functions [25]. Elements such as potassium, sodium, magnesium, iron, etc. play essential roles in maintaining human health [26-29]. Copper is involved in maintaining cardiovascular health, glucose and cholesterol metabolism [30]. Zinc is very useful in protein synthesis, cell division and maturation, immunity and sexual function [30]. The value of sodium contained in the fruits of $S$. macrocarpon grown in Cotonou $(1370.33 \mathrm{mg} / \mathrm{kg})$ was significantly lower than that of the fruit $(6238.5 \mathrm{mg} / \mathrm{kg})$ grown in Nigeria [5]. The same remark applies to the values of potassium, iron, copper and zinc. However, another study reported by [16] showed still in Nigeria that the fruits of $S$. macrocarpon studied contain less iron than those of the present study. These differences could easily be explained by the fact that the fruits do not come from the same soil. They come from different geological horizons and growing conditions are not necessarily the same. The results of this study also suggest that the fruit produced in Cotonou contain more magnesium, calcium, protein and phosphorus than those of Nigeria. Because the various elements contained in fruits are the products of secondary metabolism of plants, the value of this food should be appreciated in general and not considering each factor in isolation. To this end, we can say that the fruits of $S$. macrocarpon grown in Cotonou have interesting nutriational value, such as stated by [5] and [16] for those products in Nigeria. The leaves of $S$. macrocarpon produced in Cotonou are very nutritious as many vegetables grown in the world such as Thalinum triangulare, Momordica charantia, Moringa oleifera in Cameroon [31]; Crotalaria semperflorens in India [32]; Piliostigma thonningii [33] and Solanum melongena [34] in Nigeria. The amount of protein present in the leaves and fruits of $S$. macrocarpon is quite high and explains why it is so much appreciated by consumers. The water content of the fruits of $S$. macrocarpon is comparable to that found by [5] in Nigeria. This richness of fruits comparable to that of the leaves, which contain so much vitamins A. However, leaves are less rich invitaminK1than fruit. In addition, the high water content, low fat content of $S$. macrocarpon would favor preventive properties against constipation, colon cancer, etc. [35]. Sodipo et al. [5] have found similar results about ash content in the fruits of S. macrocarpon.

\subsubsection{Toxic Metals in Leaves and Fruits of $S$. Macrocarpon}

Lead and cadmium were detected at different values in the leaves and fruits. Although the leaves are less contaminated than the fruit by lead, it remains true that the values recorded for the two parts of the plant beyond those imposed by the AFNOR U44-041 which are 0.1 $\mathrm{mg} / \mathrm{kg}$ for cadmium, $0.3 \mathrm{mg} / \mathrm{kg}$ and $0.5 \mathrm{mg} / \mathrm{kg}$ for lead [36]. In addition, S. macrocarpon is more contaminated by lead than cadmium. This is justified because the site of Houéyiho is not an industrial site and is only subject to heavy air pollution. Lead is more specific to air pollution than cadmium which is more industrial pollutant [37]. These results differ from those reported by [5] who detected no trace of lead or cadmium in fruits of S. macrocarpon in Nigeria. This difference is explained by the fact that the site of the Nigerian study was not a mining site or an area of industrial activity and atmospheric pollution. Contrary to this, the site of Houéyiho where the fruits and leaves were acquired is located in the heart of Cotonou and subjected to a major road and air traffic. This releases heavy metals into the atmosphere, contaminating vegetable products. Similarly, the large quantities of chicken manure and organic waste used contrib.ute to contaminating the soil directly and vegetables indirectly. A study conducted six months earlier at the same site showed almost the same level of contamination of the leaves, even though it was atomic absorption spectrophotometry which was used [3]. This highlights the fact that vegetable pollution in Houéyiho is permanent and that no matter of which spectrophotometry is used (atomic or molecular), the results appear to be similar.

The leaves and fruits of $S$. macrocarpon contain chemical groups that give them interesting nutritional and medicinal properties. Despite these advantages, moderate consumption, especially of the fruit is recommended. In addition, the presence of toxic metals due to growing conditions in Cotonou requires the variation in the consumption of vegetables to avoid poisoning due to the accumulation of lead and cadmium.

\section{Acknowledgements}

Authors sincerely thank Mr. Elias POGNON, Chemical Engineer at the Laboratory for Quality Control of Water and Food (Ministry of Health) in Benin for the care. We sincerely appreciate Doctors Jacques DOUGNON and Olufunke SODIPO, M. Sika HOUNGNIHIN, Misters Alain AISSI, Alban HOUNGBEME, Mrs. Tatiana GOHOUN and Sabine MONTCHO for their various contributions.

\section{REFERENCES}

[1] CERPADEC-ONG, "Manuel de l'Apprenant en Techniques de Conduite et de Production de Cultures Maraîchères,” 2008, p. 20.

[2] G. J. H. Grubben and O. A. Denton, "Plant Resources of Tropical Africa Vegetables,” Ponennad Looijenhv, Wagen- 
ingen, 2004, p. 667.

[3] T. V. Dougnon, P. A. Edorh, H. S. Bankolé, T. J. Dougnon, S. A. Montcho, A. Hounkpatin, M. Gouissi, B. Sossou, M. Boko and E. E. Creppy, "Evaluation of the Toxicological Quality of the Leaves of Solanum macrocarpum L. Cultivated with the Chicken's Droppings and Water of Marsh at Cotonou (Benin)," Journal of Research in Environmental Science and Toxicology, Vol. 1, No. 1, 2012, pp. 1-6.

[4] O. A. Sodipo, F. I. Abdulrahman, T. E. Alemika and I. A. Gulani, "Chemical Composition and Biological Properties of the Petroleum Ether Extract of Solanum macrocarpum L. (Local Name: Gorongo)," British Journal of Pharmaceutical Research, Vol. 2, No. 2, 2012, pp. 108128.

[5] O. A. Sodipo, F. I. Abdulrahman, J. C. Akan and J. A. Akinniyi, "Phytochemical Screening and Elemental Constituents of the Fruit of Solanum macrocarpum Linn," Continental Journal of Applied Sciences, Vol. 3, 2008, pp. 85-94.

[6] V. T. Dougnon, H. S. Bankolé, P. A. Edorh, J. T. Dougnon, M. Gouissi, A. Hounkpatin, S. Montcho, H. Azonhè, J.-R. Klotoé and M. Boko, "Evaluation of the Microbiological Quality of the Leaves of Solanum macrocarpum L. Cultivated with the Chicken's Droppings and Water of Marsh in Cotonou (Republic of Benin)," International Journal of Biosciences, Vol. 2, No. 2, 2012b, pp. 45-52.

[7] F. Assogba-Komlan and P. Anihouvi, "Pratiques Culturales et Teneur en Eléments Anti Nutritionnels (Nitrates et Pesticides) du Solanum macrocarpum au Sud du Bénin," African Journal of Food, Agriculture, Nutrition and Development, Vol. 7, No. 4, 2007, pp. 1-21.

[8] P. J. Houghton and A. Raman, "Laboratory Handbook for the Fractionation of Natural Extracts," Chapman and Hall, New York, 1998, pp. 130-207. doi:10.1007/978-1-4615-5809-5

[9] Hach, "Digesdahl Digestion Apparatus: Instruction Manual for Models 23130-20-21,” Hach USA, 1999, p. 95.

[10] A. F. Gbaguidi, "Identification, Purification, Isolement et Quantifications de Principes Actifs de Mitracarpus scaber Zucc. et Evaluation de Leurs Activités Antimicrobiennes sur Dermatophilus congolensis," Thèse de Doctorat, Université d'Abomey-Calavi (Benin) et Université Catholique de Louvain (Belgique), 2005, p.176.

[11] AOAC, "Official Methods of Analysis (Section 923.03 and 962.09),” 15th Edition, Washington DC, Association of Official Analytical Chemists, 1990.

[12] D. Audigié, G. Dupont and T. Zonszain, "Manipulation d'Analyse Biochimique, ” Doin., Paris, 1978. pp. 27-74.

[13] M. E. Shils, M. Shike, A. C. Ross, B. Caballero and R. J. Cousings, "Modern Nutrition in Health and Disease," 10th Edition, Lippincott Williams and Wilkins, A Wolters Klumer Company, UK, 2006, pp. 280-281.

[14] P. M. Guimarães-Beelen, T. T. Berchielli, R. Beelen, J. A. Filho and S. G. de Oliveira, "Characterization of Condensed Tannins from Native Legumes of the Braziliannortheastern Semi-Arid," Scientia Agricola, Vol. 63, No.
6, 2006, pp. 522-528.

[15] P. K. Emebu and J. U. Anyika, "Vitamin and Antinutrient Composition of Kale (Brassica oleracea) Grown in Delta State, Nigeria," Pakistan Journal of Nutrition, Vol. 10, No. 1, 2011, pp. 76-79.

[16] S. N. Chinedu, A. C. Olasumbo, O. K. Eboji, O. C. Emiloju, O. K. Arinola and D. I. Dania, "Proximate and Phytochemical Analyses of Solanum aethiopicum L. and Solanum macrocarpon L. Fruits," Research Journal of Chemical Sciences, Vol. 1, No. 3, 2011, pp. 63-71.

[17] S. S. Gupta, "Prospects and Perspective of Natural Plant Products,” Indian Journal of Pharmacology, Vol. 26, No. 1, 1994, pp. 1-12.

[18] A. A. Olaniyi, J. S. K. Ayim, A. O. Ogundaini and T. A. Olugbade, "Essential Inorganic and Organic Chemistry," Omoade Printing Press, Ibadan, 1998, p. 582.

[19] S.-Y. Lin, H.-Y. Liu, Y.-L. Lu and W.-C. Hou, “Antioxidant Activities of Mucilages from Different Taiwanese Yam Cultivars,” Botanical Bulletin of Academia Sinica, Vol. 46, 2005, pp. 183-188.

[20] J. Bruneton, "Parmacognosie-Phytochimie-Plantes Médicinales, 3rd Édition, Éditions Tec \& Doc et Médicales Internationales, Cachan, Paris, 1999, p. 1120.

[21] A. L. Otshudi, A. Vercruysse and A. Foriers, "Contribution to the Ethnobotanical, Phytochemical and Pharmacological Studies of Traditionally Used Medicinal Plants in the Treatment of Dysentery and Diarrhoea in Lomola Area, Democratic Republic of Congo (RDC)," Journal of Ethnopharmacology, Vol. 71, No. 3, 2000, pp. 411-423. doi:10.1016/S0378-8741(00)00167-7

[22] P. R. Cheek, "Nutritional and Physiological Implications of Saponins: A Review," Canadian Journal of Animal Science, Vol. 51, No. 3, 1971, pp. 621-632. doi:10.4141/cjas71-082

[23] E. Y. Ladiguina, L. N. Safronich, V. E. Otriacheva, I. A. Balandina, N. I. Grinkevich, A. A. Sorokina, V. I. Glizin, L. M. Molodojnikova, Y. S. Mitin, I. A. Samilina and V. A. Ermakova, "Khimicheskii Analiz Lekarstvenii Rastenii,” Moskva Vischaya Chkola, 1983, p. 172.

[24] G. V. Lazureskii, I. V. Terenteva and A. A. Chamchurin, "Praticheskii Raboti po Khimii Soedinienii," Édition Vischaya Chkola, Moscou, 1966, p. 334.

[25] K. M. Roberts, K. G. Daryl, A. M. Peter and W. K. Victor, "Harper's Biochemistry," 25th Edition, Lange Medical Book, Appleton and Lange, 2000, pp. 209-210.

[26] H. A. Schroeder, “Trace Element and Nutrition,” Faber, London, 1976, pp. 30-46.

[27] E. A. Moses, V. O. Ogugbuaja and V. C. Ogarawu, "Enrichment of Element of Nigerian Bituminous Coal Fly Ash and Their Effects on Haematological Parameters of Exposed Rabbits," Nigerian Journal of Experimental and Applied Biology, Vol. 3, No. 1, 2002, pp. 95-100.

[28] F. I. Abdulrahman, "Studies in the Chemical Contents and Pharmacological Activities of the Root-Bark Extract of Vitex doniana (Black Plum),” Ph.D. Thesis, University of Maiduguri, Maiduguri, 2004, pp. 55-82.

[29] Y. Karumi, "Chemical and Pharmacological Studies of 
Momordica balsamina (Balsam Apple) Leaf Extract," Ph.D. Thesis, University of Maiduguri, Maiduguri, 2005, pp. 58-96.

[30] H. H. Sandstead, J. G. Penland, N. W. Alcock, H. H. Dayal, X. C. Chen, J. S. Li, F. Zhao and J. J. Yang, "Effects of Repletion with Zinc and Other Micronutrients on Neuropsychologic Performance and Growth of Chinese Children," The American Society for Clinical Nutrition, Vol. 68, No. 2, pp. 470S-475S.

[31] C. Tchiégang and K. Aissatou, "Données Ethnonutritionnelles et Caractéristiques Physico-Chimiques des LégumesFeuilles Consommés Dans la Savane de l'Adamaoua (Cameroun), Tropicultura, Vol. 22, No. 1, 2004, pp. 1118.

[32] P. Kathirvel, "A Study on the Proximate and Mineral Composition of Crotalaria semperflorens Vent," International Journal of Applied Biology and Pharmaceutical Technology, Vol. 3, No. 1, 2012, pp. 64-66.

[33] O. M. Ighodaro, S. O. Agunbiade, J. O. Omole and O. A. Kuti, "Evaluation of the Chemical, Nutritional, Antimicrobial and Antioxidant-Vitamin Profiles of Piliostigma thonningii Leaves (Nigerian species)," Research Journal of Medicinal Plant, Vol. 6, No 7, 2012, pp. 537-543. doi:10.3923/rimp.2012.537.543

[34] B. O. Agoreyo, E. S. Obansa and E. O. Obanor, “Comparative Nutritional and Phytochemical analyses of Two Varieties of Solanum melongena," Science World Journal, Vol. 7, No. 1, 2012, pp. 5-8.

[35] F. A. Showemimo and J. D. Olarewaju, “Agro-Nutritional Determinants of Some Garden Varieties (Solanum gilo L.)," Journal of Food and Technology, Vol. 2, No. 3, 2004, pp. 172-175.

[36] Ctifl, "Le Point sur la Maîtrise de la Qualité Hygiénique des Salades, ” Imprimerie Centr’Imprim, France, 2001, p. 4.

[37] T. V. Dougnon, P. A. Edorh, H. S. Bankolé, T. J. Dougnon, S. Salifou, L. Koumolou, S. A. Montcho and M. Boko, "Evaluation of the Toxicological Quality of Chicken's Droppings Used for the Culture of Solanum macrocarpum L. in Cotonou (Republic of Benin)," International Journal of Advanced Biological Research, Vol. 2, No. 1, 2012, pp. 91-94. 